\title{
MINERAL COMPOSITION AND SOME QUALITY CHARACTERISTICS OF ICE CREAMS MANUFACTURED WITH THE ADDITION OF BLUEBERRY
}

\author{
Tuba Erkaya Kotan* \\ Department of Food Processing, Erzurum Vocational High School, Atatürk University, Erzurum, Turkey
}

Received / Geliş: 30.03.2018; Accepted / Kabul: 08.06.2018; Published online / Online bask1: 05.07.2018

Erkaya Kotan, T. (2018). Mineral composition and some quality characteristics of ice creams manufactured with the addition of blueberry. GID $A$ (2018) 43 (4): 635-643 doi: 10.15237/gida.GD18042

\begin{abstract}
In this study, determination of some physicochemical (total dry matter, fat, ash, protein, titratable acidity, $\mathrm{pH}$, complete melting time and first dripping times), sensory properties (color and appearance, resistant to melting, body and texture, flavor, gumming structure, general acceptability), and mineral contents of ice cream produced by adding blueberry (Vaccinium myrtillus L.) at different ratios was aimed. Ice creams consisted of four different samples which are control, containing 5\%,10\% and 15\% blueberry (BB), respectively. In the experimental ice cream samples, a decrease in total solid, fat, protein, $\mathrm{pH}$ and complete melting time was observed with the increment of $\mathrm{BB}$, while an increase was determined in overrun and viscosity values. $\mathrm{BB}$ addition was also increased the contents of $\mathrm{K}, \mathrm{Zn}, \mathrm{Mn}$ and Se minerals of the ice creams. While there was no statistically significant difference in the scores given by panelists to ice cream samples, a significant $(p<0.05)$ decrease in only gumming structure scores was observed with the increase in BB addition.
\end{abstract}

Keywords: Ice cream, blueberry, mineral composition, physicochemical and sensory analyses

\section{YABAN MERSİNİ İLAVESIYYLE ÜRETİLEN DONDURMALARIN MİNERAL İÇERİKLERİ VE BAZI KALİTE ÖZELLİKLERİ}

\section{ÖZ}

Bu çalışmada farklı oranlarda yaban mersini (Vaccinium myrtillus L.) ilavesiyle üretilen dondurmaların baz1 fizikokimyasal (toplam kurumadde, yağ, kül, protein, titrasyon asitliği, $\mathrm{pH}$, toplam erime süresi ve ilk damlama süreleri) ve duyusal özellikleri (renk ve görünüş, erime direnci, yapı ve tekstür, lezzet, sakızımsı yapı, genel kabul edilebilirlik) ile mineral içeriklerinin belirlenmesi amaçlanmıştır. Dondurmalar sırasıyla kontrol, $\% 5, \% 10$ ve $\% 15$ oranlarında yaban mersini (YM) içeren olmak üzere 4 farklı örnekten oluşmuştur. Deneme dondurma örneklerinde YM oranının artışıly toplam kurumadde, yağ, protein, $\mathrm{pH}$ ve toplam erime süresi değerlerinde azalma görülürken, hacim artışı ve viskozite değerlerinde ise artış tespit edilmiştir. YM ilavesi dondurmaların K, Zn, Mn ve Se mineralleri içeriklerini de artırmıştır. Dondurma örneklerine panelistler tarafından verilen puanlarda genel olarak istatistiksel bir fark görülmezken, YM ilavesinin artışı ile yalnızca sakızımsı yapı puanlarında önemli $(p<0.05)$ bir azalma saptanmıştır.

Anahtar kelimeler: Dondurma, yaban mersini, mineral kompozisyon, fizikokimyasal ve duyusal analizler

* Corresponding author / Yazışmalardan sorumlu yazar;

$\triangle$ terkaya@atauni.edu.tr,

(f)(+90) 4422312288

且(+90) 4422312503 


\section{INTRODUCTION}

Ice cream is one of the most consumed frozen dairy products in worldwide (Gorski, 1997), and in recent years, its production has increased rapidly. However, the commercially available ice cream is generally lacking in natural antioxidants like vitamin C, polyphenols and pigments. Therefore, it is interesting to find out the possibilities of improving the nutritional properties of ice cream using some ingredients having health benefits (El-Nagar et al., 2002; Van Kleef et al., 2002; Gidley, 2004). Using fruits in the ice cream production provides some nutritional benefits due to their natural antioxidants, anthocyanin, colorants, vitamins and minerals in light of consumer demands. The fundamental characteristics of many fruits or plants, especially their potential use as novel nutraceuticals in functional foods are being investigated. Recently, use of some ingredients with nutritional and physiological properties such as some fruits, fruit products, fruit juices, alternative sweeteners, dietary fibers, probiotics and other additives in ice cream production has rapidly increased owing to demand of consumers to the beneficial foods (Diplock et al., 1999; Balthazar et al., 2015).

Berries have comparatively high antioxidant activity with their contents of anthocyanin and total phenolic compounds (Heinonen et al., 1998; Pior et al., 1998; Connor et al., 2002; Primetta et al., 2013). Many of the beneficial effects related with berry fruits may be due to the high concentrations of anthocyanin compounds. Scientific reports recommend that anthocyaninrich berries or its products show great protective effects with potential advantages for human and animal health. Anthocyanins may also act as antioxidative, antienflammatory, neuroprotective, vasoprotective and inhibitor for the growth of cancerous cells have been stated (Kong et al., 2003). Among the berry species, blueberry is also rich source of the naturally occurring phenolic pigments, anthocyanins and antioxidants. Also, blueberry is an excellent source of fiber and has a low amount of calories and sodium content (Saral et al., 2014). Blueberry (V accinium myrtillus L.) is generally growth different regions in Northern
America, Europe and Northern Asia. In Turkey, Vaccinium myrtillus L. is largely found in Artvin, Rize, Trabzon, Giresun and Ordu, and offer a variety of wildlife (Çelik, 2004; Saral et al., 2014). Recently, cultivation of blueberry has become popular, because of increasing international demand for its berries (Gümüş et al., 2009).

Chemical composition of blueberry forms of $87.70 \%$ moisture, $0.48 \%$ protein, $0.19 \%$ lipid, $11.54 \%$ carbohydrates, $1.90 \%$ dietary fibres, vitamins and mineral substances (calcium, magnesium, potassium, iron, zinc and phosphorus) (de Souza et al., 2014). Konic'Ristic' et al. (2011) investigated mineral composition of berry juices and they emphasized that berry juices are good sources of some minerals, and based on average intake of berries and related products contribute significantly to daily intake of these micronutrients. The consumption of blueberries has been suggested by the researchers due to their effects on suppression oxidative stress (Sellappan et al. 2002; Ahmet et al. 2009), infections (Sweeney et al., 2002), and kidney injury (Nair et al., 2014), and improvement of vascular health (Erlund et al., 2008). These useful properties have been imputed to bioactive berry compounds, relatively high phenolic compounds, in particular anthocyanins (Subash et al., 2014). In spite of its useful effects, the consumption of blueberry fruit is not very common in Turkey. Owing to many beneficial effects of this fruit, one of the goals of this study is to contribute to its consumption investigating the possibilities of producing ice cream with blueberry. Furthermore, consumer demands for processed foods are that they are in their natural colors. From this point, another aim of this study to enhance the color of ice cream using this fruit.

Briefly, the aims of this work were to study possibility of production a new functional food, to increase the nutraceutical potential and nutritive value of ice cream using blueberry (Vaccinium myrtillus L.) as a natural ingredient and to evaluate the effect of blueberry on the chemical and sensory characteristics and mineral concentrations of ice cream. 


\section{MATERIALS AND METHODS \\ Materials}

Cows' milk and cream were obtained by the Research and Application Farm of Ataturk University. The blueberry was collected from cultivated fields in Rize in Turkey. Sugar, salep and emulsifier (mono- and di-glycerides) were obtained from local markets. Skim milk powder was supplied by Pinar Dairy Products Co. (Turkey).

\section{Ice cream Manufacture}

Ice cream samples were produced in the Pilot Plant of Food Engineering Department, Atatürk University. The mixes of ice creams were prepared by setting fat ratio of cows' milk to $6 \%$ with cream addition. Afterwards, the milk was divided into 4 equal parts of $3.5 \mathrm{~kg}$. For each mix $3.75 \%$ skim milk powder, $10 \%$ sugar, $0.7 \%$ salep (stabilizer) and $0.25 \%$ emulsifier (mono- and diglycerides) were added. The sugar ratio was $15 \%$ in control mix. The mixes were pasteurized at 85 ${ }^{\circ} \mathrm{C}$ for $25 \mathrm{~min}$ and were rapidly cooled to $4{ }^{\circ} \mathrm{C}$ and remained at constant temperature for $24 \mathrm{~h}$ to be aged. The first mix was taken as the control (C) and the other mixes $\left(\mathrm{BB}_{5 \%}, \mathrm{BB}_{10 \%}, \mathrm{BB}_{15 \%}\right)$ were prepared with different levels of the blueberry (BB) after the fruit minced into small pieces. They were frozen in ice cream machinery (-5 C) (Ugur Cooling Machineries Co., Nazilli Turkey) and hardened at $-22^{\circ} \mathrm{C}$ for one day and stored at $-18^{\circ} \mathrm{C}$ throughout physical, chemical and sensory analysis. Ice cream manufacture was performed in duplicate.

\section{Chemical and Mineral Analyses}

The total solid (\%) and ash (\%) contents of ice cream samples were determined using the gravimetric method, fat content $(\%)$ by the Gerber method and protein content (\%) using the Kjeldahl method. The $\mathrm{pH}$ was measured using a pH meter (model WTW pH-340-A, Weilheim, Germany) fitted with a combined glass electrode. The titratable acidity was determined as lactic acid percentage by titrating with $0.1 \mathrm{~N} \mathrm{NaOH}$, using phenolphthalein as an indicator (AOAC International, 2000).
For the measurement of nutraceutical potential of blueberry, mineral composition were determined in ice cream samples. Mineral contents $(\mathrm{Ca}, \mathrm{Mg}$, $\mathrm{Na}, \mathrm{P}, \mathrm{K}, \mathrm{Fe}, \mathrm{Mn}, \mathrm{Ni}, \mathrm{S}, \mathrm{Zn}$ ) of ice cream samples were detected using an Inductively Couple Plasma spectrophotometer (Perkin-Elmer, Optima 2100 DV, ICP/OES, Shelton, CT, USA) and following the method proposed by Güler (2007). Decomposition of ice cream samples was performed in a microwave oven (Berghof speed wave, Germany). For this purpose, about $0.5 \mathrm{~g}$ ice-cream sample was weighed into the digestion vessels. Concentrated nitric acid $(10 \mathrm{~mL})$ was added and after that, digestion was carried out to each sample at $210{ }^{\circ} \mathrm{C}$ and 176 psi pressure for 10 min. After cooling, the carousels were removed from the oven, $30 \%$ hydrogen peroxide $(2 \mathrm{~mL})$ was added to samples and then second digestion was applied at $195{ }^{\circ} \mathrm{C}$ and 95 psi pressure for 5 min. The vessels were immediately closed after the addition of oxidants. At the end of the digestion process, the samples were diluted with distilled water to a suitable concentration, and were filtered through Whatman no. 42 filter paper. All diluted digests were eventually analyzed by an Inductively Couple Plasma spectrophotometer (ICP-OES).

\section{Physical Analyses}

For determination of first dripping and complete melting times, the method of Güven and Karaca (2002) was used. The tempered samples (25 g) were left to melt (at room temperature, $20^{\circ} \mathrm{C}$ ) on a $0.2 \mathrm{~cm}$ wire mesh screen above a beaker. First dripping and complete melting times of samples were determined as seconds. Overrun was calculated according to the equation [(volume of ice cream) - (volume of mix) / volume of mix $\times$ 100] given by Jimenez-Florez, Klipfel and Tobias (1993), using a standard $100 \mathrm{ml}$ cup. The viscosities of the mixes were taken at $4{ }^{\circ} \mathrm{C}$ using a digital Brookfield Viscometer, Model DV-II (Brookfield Engineering Laboratories, Stoughton, MA, USA) with an RV spindle set (spindle No. 2) at $50 \mathrm{rpm}$. Before measurement of the viscosity, the samples were stirred gently (Özer et al., 1997). 


\section{Sensory Analysis}

The sensory evaluation of the ice cream samples was conducted by 8 panelists using a score test for flavour, body and texture, colour and appearance, resistant to melting and general acceptability. Hardened ice cream samples were tested at a serving temperature of $-10{ }^{\circ} \mathrm{C}$. The sensory characteristics were assessed on a scale from 1 , for very poor, to 9, for excellent (Roland et al., 1999).

\section{Statistical Analysis}

The data were analyzed statistically using SPSS statistical software programme version 13 (SPSS Inc., Chicago, IL, USA) Analysis of variance (ANOVA) and Duncan's Multiple Range Test was used to determine significant differences among results.

\section{RESULTS AND DISCUSSION \\ Physical and chemical characteristics of ice creams}

Table 1 shows the results of gross chemical composition and physicochemical properties of ice cream samples. For compositional properties of the ice cream samples total solids, protein, fat and ash contents were detected. The addition of $\mathrm{BB}$ significantly affected the gross chemical composition except for ash values of ice cream samples $(P<0.05)$. As expected, the increment of $\mathrm{BB}$ caused a decrease in total solids, protein and fat values of the ice creams. Also, Öztürk et al. (2018) detected that dark and white blue fruits pulp addition caused a decrease in the protein, ash and fat contents of ice creams. On the hand, this result was in contrast with the results in ice cream added Cape gooseberry found by Erkaya et al. (2012).

Table 1. Effect of the addition of blueberry on the gross chemical composition of ice creams

\begin{tabular}{lcccc}
\hline Ice cream samples & Total Solids $(\%)$ & Ash $(\%)$ & Fat $(\%)$ & Protein $(\%)$ \\
\hline $\mathrm{C}$ & $28.73 \pm 0.93^{\mathrm{c}}$ & $0.73 \pm 0.01^{\mathrm{a}}$ & $5.60 \pm 0.00^{\mathrm{c}}$ & $5.11 \pm 0.16^{\mathrm{b}}$ \\
$\mathrm{BB}_{5 \%}$ & $29.07 \pm 0.23^{\mathrm{c}}$ & $0.71 \pm 0.03^{\mathrm{a}}$ & $5.40 \pm 0.14^{\mathrm{bc}}$ & $4.53 \pm 0.52^{\mathrm{ab}}$ \\
$\mathrm{BB}_{10 \%}$ & $27.91 \pm 0.13^{\mathrm{b}}$ & $0.70 \pm 0.04^{\mathrm{a}}$ & $4.85 \pm 0.07^{\mathrm{ab}}$ & $3.92 \pm 0.31^{\mathrm{a}}$ \\
$\mathrm{BB}_{15 \%}$ & $26.83 \pm 0.04^{\mathrm{a}}$ & $0.69 \pm 0.02^{\mathrm{a}}$ & $4.30 \pm 0.42^{\mathrm{a}}$ & $3.95 \pm 0.07^{\mathrm{a}}$ \\
\hline
\end{tabular}

${ }_{1}^{1}$ Mean values followed by different letters in the same column are significantly different $(P<0.05)$

${ }^{2} \mathrm{C}$ : control without blueberry, $\mathrm{BB}_{5 \%}: 5 \%(\mathrm{w} / \mathrm{w})$ blueberry added, $\mathrm{BB}_{10 \%}: 10 \%(\mathrm{w} / \mathrm{w})$ blueberry added, $\mathrm{BB}_{15 \%}: 15 \%$ (w/w) blueberry added.

The titratable acidity values of the samples ranged from $0.24-0.44 \%$. It was observed that a constant increase in titratable acidity while a decrease in $\mathrm{pH}$ values of the samples as increasing concentrations of $\mathrm{BB}$ (Table 2). The decrease of $\mathrm{pH}$ may be resulted from the existence of various natural acid compounds in berries, such as ascorbic acid, fatty acids, etc. So, these acids naturally found in $\mathrm{BB}$ might be reduced $\mathrm{pH}$ values of the ice cream samples as well as to increase the acidity values.

Table 2. Effect of the addition of blueberry on the physicochemical properties of ice creams

\begin{tabular}{lcccccc}
\hline $\begin{array}{l}\text { Ice } \\
\text { cream } \\
\text { samples }\end{array}$ & $\begin{array}{c}\text { Titratable } \\
\text { acidity (\%) }\end{array}$ & $\mathrm{pH}$ & $\begin{array}{c}\text { Viscosity } \\
(\mathrm{cP})\end{array}$ & $\begin{array}{c}\text { Overrun } \\
(\%)\end{array}$ & $\begin{array}{c}\text { Complete } \\
\text { Melting } \\
\text { Times (s) }\end{array}$ & $\begin{array}{c}\text { First dripping } \\
\text { time (s) }\end{array}$ \\
\hline $\mathrm{C}$ & $0.24 \pm 0.00^{\mathrm{a}}$ & $6.56 \pm 0.02^{\mathrm{d}}$ & $950 \pm 14.14^{\mathrm{a}}$ & $20.33 \pm 1.39^{\mathrm{a}}$ & $7470 \pm 42.43^{\mathrm{d}}$ & $1380 \pm 169.70^{\mathrm{a}}$ \\
$\mathrm{BB}_{5 \%}$ & $0.35 \pm 0.03^{\mathrm{b}}$ & $6.14 \pm 0.04^{\mathrm{c}}$ & $1165 \pm 21.21^{\mathrm{b}}$ & $22.96 \pm 1.27^{\mathrm{ab}}$ & $6300 \pm 0.00^{\mathrm{c}}$ & $1500 \pm 69.71^{\mathrm{a}}$ \\
$\mathrm{BB}_{10 \%} \%$ & $0.38 \pm 0.01^{\mathrm{b}}$ & $5.96 \pm 0.04^{\mathrm{b}}$ & $1645 \pm 35.35^{\mathrm{b}}$ & $24.45 \pm 1.27^{\mathrm{b}}$ & $4680 \pm 0.00 \mathrm{~b}$ & $1440 \pm 84.85^{\mathrm{a}}$ \\
$\mathrm{BB}_{15 \%}$ & $0.44 \pm 0.00^{\mathrm{c}}$ & $5.76 \pm 0.05^{\mathrm{a}}$ & $1350 \pm 141.4^{\mathrm{c}}$ & $25.61 \pm 1.06^{\mathrm{b}}$ & $4530 \pm 42.43^{\mathrm{a}}$ & $1440 \pm 169.71^{\mathrm{a}}$ \\
\hline
\end{tabular}

${ }^{1}$ Mean values followed by different letters in the same column are significantly different $(P<0.05)$

${ }^{2} \mathrm{C}$ : control without blueberry, $\mathrm{BB}_{5 \%}: 5 \%(\mathrm{w} / \mathrm{w})$ blueberry added, $\mathrm{BB}_{10 \%}: 10 \%(\mathrm{w} / \mathrm{w})$ blueberry added, $\mathrm{BB}_{15 \%}: 15 \%$ (w/w) blueberry added. 
Overrun value is a measure of air amount of ice cream for identifying of the final product's structure (Sofjan and Hartel, 2004). As seen in Table 2, the percentage of overrun among ice cream samples with BB was significantly different than control sample and the highest overrun value was determined in sample $\mathrm{BB}_{15 \%}(25.61 \%)$. Akin (1990) denoted that the difficulty in increasing the overrun over $35-40 \%$ in soft and semisoft ice creams produced in batch-type freezing machines. However, BB addition increased overrun values of the ice creams. This may be resulted from the physicochemical properties of $\mathrm{BB}$ which had a juicy and soft structure. Viscosity of mix affects body and texture for this reason it is an important characteristic of ice cream. The viscosity values of ice cream samples with $B B$ increased significantly when compared to the control group (Table 2). Similar results were found in grape wine lees added ice cream by Hwang et al. (2009), in frozen yogurt by Güven and Karaca (2002) and in ice cream with green tea powder Yüksel et al. (2017).

The melting resistance of ice cream is affected by many factors, including the amount of air incorporated, the nature of the ice crystals, and the network of fat globules formed during freezing (Bolliger et al., 2000; Muse and Hartel, 2004). As shown in Table 2., control sample (C) had the longest complete melting times value (7470 s) followed by $\mathrm{BB}_{5 \%}, \mathrm{BB}_{10} \%$ and $\mathrm{BB}_{15 \%}$ samples (6300, 4680, $4530 \mathrm{~s}$, respectively). This might be explained by the physicochemical properties of BB. The decrease of complete melting times for ice creams with BB was in agreement with the results indicated by Kavaz Yüksel (2015) who studied the effects of blackthorn addition on the ice cream characteristics. The first dripping times values ranged from 1380 to $1500 \mathrm{~s}$. The addition of BB to the ice cream did not affected the first dripping times values. In light of these results, it could be stated that BB had major significance on melting times of ice cream.

\section{Mineral contents of ice cream samples}

Table 3. demonstrates the major elements detected in the ice cream samples. In general, the major elements of ice cream samples were not significantly affected by addition of BB. However, $\mathrm{Ca}$ and $\mathrm{K}$ minerals demonstrated statistically significant differences between control ice cream and others $(P<0.05)$. Ca levels of ice creams showed a significant decrease with the addition of $\mathrm{BB}$, it was ranged as $533.25-1051.21 \mathrm{mg} / \mathrm{kg}$ from control sample to $\mathrm{BB}_{15 \%}$ sample. Conversely, $\mathrm{K}$ content reached to level of $14264 \mathrm{mg} / \mathrm{kg}$ with the addition of $15 \% \mathrm{BB}$ to the ice cream samples. Konic'-Ristic' et al. (2011) investigated the chemical composition of different berry juices and also compared mineral contents of them. They reported that the major element in berry juices was $\mathrm{K}$ and its content ranged from 92.9 $\mathrm{mg} / 100 \mathrm{~g}$ to $208.7 \mathrm{mg} / 100 \mathrm{~g}$. They also stated that berry fruits were good sources of some minerals and contributed significantly to daily intake of these micronutrients. Szefer and Nriagu (2007) reported that $\mathrm{K}$ had a crucial importance on the physiological functions of the human body. Erkaya et al. (2012) reported that the addition of CG increased the $\mathrm{K}$ content of the ice cream samples and the highest mineral was found to be $\mathrm{K}$ in all samples. On the other hand, $\mathrm{Ca}$ contents of ice cream samples added BB decreased with the increase of fruit levels. The decrease in the concentration of $\mathrm{Ca}$ in the enriched ice cream samples was due to the low $\mathrm{Ca}$ content of the blueberry fruit. In the contrary, the increase in the concentration of $\mathrm{K}$ in the enriched ice cream samples was due to the high amount of $\mathrm{K}$ in the blueberry fruit.

$\mathrm{Fe}, \mathrm{Mn}, \mathrm{Ni}, \mathrm{Cu}, \mathrm{Zn}$, Se and Mo are defined as micro elements. The essential minor elements have four major functions as stabilizers, essential elements for hormonal function, elements of structure and cofactors in enzymes (Feinendegen and Kasperek, 1980). Changes in micro element values in ice cream samples are presented in Table 4. $\mathrm{Cu}, \mathrm{Fe}, \mathrm{Zn}, \mathrm{Mn}$, Se and $\mathrm{Ni}$ were determined as minor elements in ice cream samples. The addition of $\mathrm{BB}$ significantly increased $\mathrm{Zn}, \mathrm{Mn}$ and Se contents of the ice creams $(P<0.05)$. $\mathrm{Zn}$ and $\mathrm{Se}$ play an important role in the human body such as enzymes and proteins, hormones, growth, antioxidant property, skin and wound healing, immune systems, water and caution balance, 
behavior and learning ability. The bioavailability of Se in fruits, vegetables and cereal products are higher than that in other foods (Şimşek et al., 2004). Similarly, Mn affects enzyme activity, bone growth, lipid and carbohydrate metabolism, cell, structure, immune and brain functions (McDowell, 2003). As seen in Table 4, BB supplementation up to $15 \%$ provided an increase approximately 10 times in $\mathrm{Mn}$ contents of ice cream sample when compared to control sample. Besides, Se and $\mathrm{Zn}$ values increased approximately 2 times in ice cream with the addition of $15 \% \mathrm{BB}$. These results are important especially in terms of increasing the nutritional value of ice cream.

Table 3. Effect of the addition of blueberry on the major elements $(\mathrm{mg} / \mathrm{kg})$ of ice creams

\begin{tabular}{lcccccc}
\hline $\begin{array}{l}\text { Ice } \\
\text { cream } \\
\text { samples }\end{array}$ & $\mathrm{Ca}$ & $\mathrm{K}$ & $\mathrm{P}$ & $\mathrm{S}$ & $\mathrm{Na}$ & $\mathrm{Mg}$ \\
\hline $\mathrm{C}$ & $1051.21 \pm 72^{\mathrm{b}}$ & $8994 \pm 8.48^{\mathrm{a}}$ & $5226.61 \pm 551^{\mathrm{a}}$ & $2091.93 \pm 942^{\mathrm{a}}$ & $10354.50 \pm 715^{\mathrm{a}}$ & $670.58 \pm 53.21^{\mathrm{a}}$ \\
$\mathrm{BB}_{5 \%}$ & $649.91 \pm 194^{\mathrm{a}}$ & $12076 \pm 643.46^{\mathrm{b}}$ & $5075.63 \pm 772^{\mathrm{a}}$ & $1649.23 \pm 89^{\mathrm{a}}$ & $10896.65 \pm 12^{\mathrm{a}}$ & $725.50 \pm 8.47^{\mathrm{a}}$ \\
$\mathrm{BB}_{10 \%} \%$ & $469.36 \pm 39^{\mathrm{a}}$ & $13183 \pm 830.85^{\mathrm{bc}}$ & $5065.86 \pm 941^{\mathrm{a}}$ & $1442.61 \pm 94^{\mathrm{a}}$ & $10855.65 \pm 176^{\mathrm{a}}$ & $731.01 \pm 0.04^{\mathrm{a}}$ \\
$\mathrm{BB}_{15 \%}$ & $533.25 \pm 77^{\mathrm{a}}$ & $14264 \pm 562.14^{\mathrm{c}}$ & $4754.46 \pm 125^{\mathrm{a}}$ & $1344.64 \pm 48^{\mathrm{a}}$ & $10870.65 \pm 613^{\mathrm{a}}$ & $762.82 \pm 56.71^{\mathrm{a}}$ \\
\hline
\end{tabular}

${ }^{1}$ Mean values followed by different letters in the same column are significantly different $(P<0.05)$

${ }^{2} \mathrm{C}$ : control without blueberry, $\mathrm{BB}_{5 \%}: 5 \%(\mathrm{w} / \mathrm{w})$ blueberry added, $\mathrm{BB}_{10 \%}: 10 \%$ (w/w) blueberry added, $\mathrm{BB}_{15 \%}: 15 \%$ $(\mathrm{w} / \mathrm{w})$ blueberry added.

Table 4. Effect of the addition of blueberry on the minor elements $(\mathrm{mg} / \mathrm{kg})$ of ice creams

\begin{tabular}{lcccccc}
\hline $\begin{array}{l}\text { Ice cream } \\
\text { samples }\end{array}$ & $\mathrm{Cu}$ & $\mathrm{Fe}$ & $\mathrm{Mn}$ & $\mathrm{Ni}$ & $\mathrm{Se}$ & $\mathrm{Zn}$ \\
\hline $\mathrm{C}$ & $25.33 \pm 4.70^{\mathrm{a}}$ & $57.06 \pm 23.18^{\mathrm{a}}$ & $0.30 \pm 0.14^{\mathrm{a}}$ & $1.52 \pm 0.99^{\mathrm{a}}$ & $1.57 \pm 0.09^{\mathrm{a}}$ & $47.71 \pm 0.42^{\mathrm{a}}$ \\
$\mathrm{BB}_{5 \%}$ & $21.43 \pm 0.22^{\mathrm{a}}$ & $77.80 \pm 37.58^{\mathrm{a}}$ & $4.27 \pm 0.14^{\mathrm{b}}$ & $3.87 \pm 1.31^{\mathrm{a}}$ & $2.49 \pm 0.26^{\mathrm{b}}$ & $50.84 \pm 16.28^{\mathrm{a}}$ \\
$\mathrm{BB}_{10 \%}$ & $20.25 \pm 39.11^{\mathrm{a}}$ & $64.11 \pm 25.45^{\mathrm{a}}$ & $8.17 \pm 0.13^{\mathrm{c}}$ & $2.78 \pm 0.41^{\mathrm{a}}$ & $2.71 \pm 0.23^{\mathrm{b}}$ & $48.30 \pm 1.26^{\mathrm{a}}$ \\
$\mathrm{BB}_{15 \%}$ & $23.64 \pm 9.59^{\mathrm{a}}$ & $49.36 \pm 5.21^{\mathrm{a}}$ & $11.81 \pm 0.38^{\mathrm{d}}$ & $2.92 \pm 0.30^{\mathrm{a}}$ & $2.97 \pm 0.38^{\mathrm{b}}$ & $89.04 \pm 12.08^{\mathrm{b}}$ \\
\hline
\end{tabular}

${ }^{1}$ Mean values followed by different letters in the same column are significantly different $(P<0.05)$

${ }^{2} \mathrm{C}$ : control without blueberry, $\mathrm{BB}_{5 \%}: 5 \%$ (w/w) blueberry added, $\mathrm{BB}_{10 \%}: 10 \%$ (w/w) blueberry added, $\mathrm{BB}_{15 \%}: 15 \%$ $(\mathrm{w} / \mathrm{w})$ blueberry added.

\section{Sensory characteristics of ice cream samples}

Sensory attributes of the ice cream samples on a scale from 1 (very bad) to 9 (excellent) are profiled in a radar in Figure 1. All the samples received high scores for total evaluation in terms of sensory properties. According to the statistical evaluations, the addition of $\mathrm{BB}$ had no effect $(P>0.05)$ on the scores of colour and appearance, resistant to melting, flavour, body and texture, and general acceptability characteristics.
However, gumming structure scores of the ice cream samples were significantly affected $(P$ $<0.05)$ by the incorporation of BB. The scores for gumming structure were significantly decreased with the increase of $\mathrm{BB}$ concentration. This result was parallel to the analysis of complete melting times. So, the improved mouthfeel of the samples containing fruit may be associated with increased meltability. 


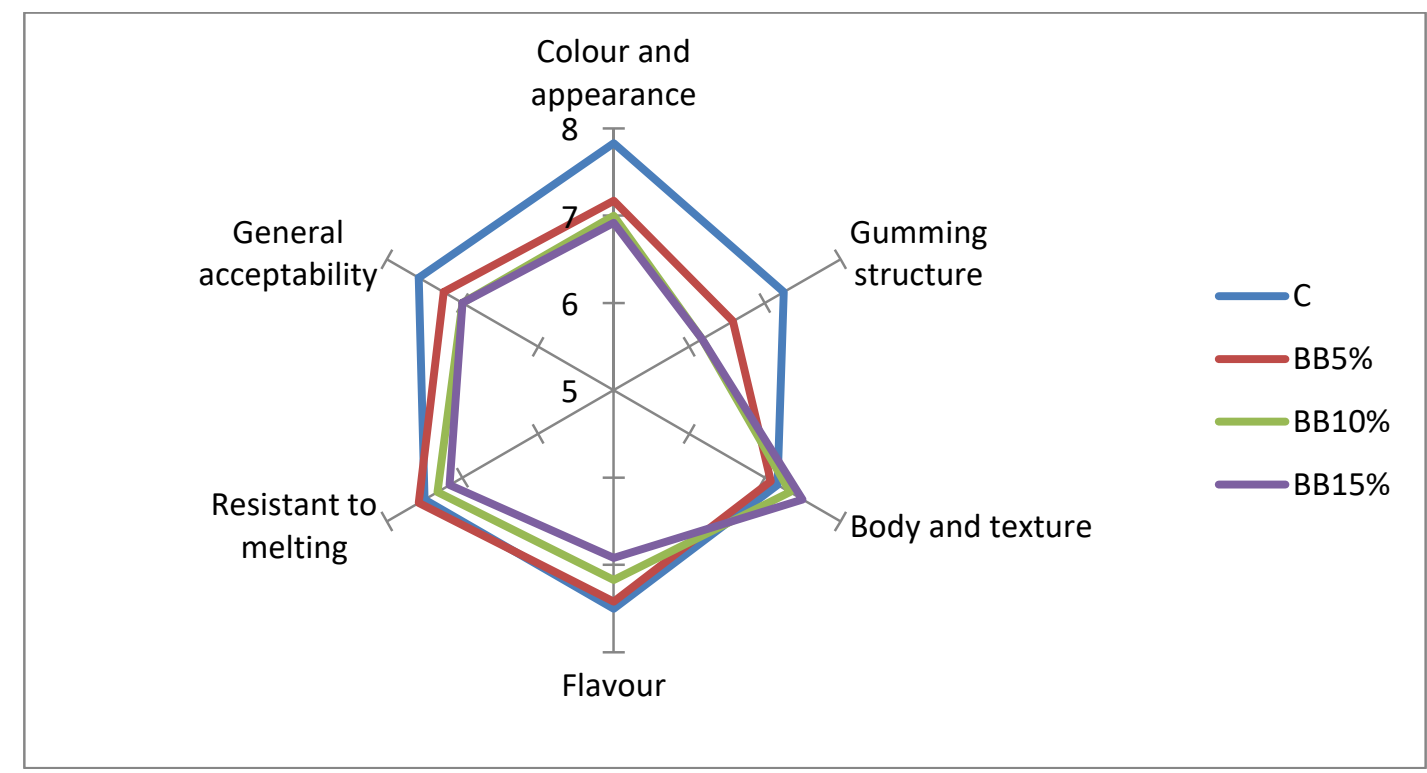

Fig. 1. Changes in sensory profiles of ice cream samples

(C: control without blueberry, $\mathrm{BB}_{5 \%}: 5 \%(\mathrm{w} / \mathrm{w})$ blueberry added, $\mathrm{BB}_{10 \%}: 10 \%(\mathrm{w} / \mathrm{w})$ blueberry added, $\mathrm{BB}_{15 \%}: 15 \%(\mathrm{w} / \mathrm{w})$ blueberry added.)

\section{CONCLUSION}

In conclusion, results of this study demonstrated that the addition of blueberry improved some quality and nutritional properties of ice cream. It was observed that $\mathrm{BB}$ addition significantly contributed to increase some major and minor elements of ice cream such as $\mathrm{K}, \mathrm{Se}, \mathrm{Mn}$ and $\mathrm{Zn}$ which have vital importance for the human body. Also, ice cream samples with BB had taken good scores by the panelists. Therefore, it can be recommended that BB may be added to ice cream as a natural source to increase nutritional values and to develop physicochemical properties.

\section{REFERENCES}

Ahmet, I., Spangler, E., Shukitt-Hale, B., Juhaszova, M., Sollott, S.J., Joseph, J.A.(2009). Blueberry-enriched diet protects rat heart from ischemic damage. PLoS ONE, 4(6): e5954.

Akin, M.S. (1990). Inek, Keci ve Koyan Sutlerinden Uretilen Dondurmalarin Kimyasal, Fiziksel ve Duyusal Bazi Ozelliklerinin Saptanmasi Uzerine Karsilastirmali Arastirma. Adana: Yuksek Lisans Tezi, Cukurova Universitesi Ziraat Fakultesi Basimevi.
AOAC International. 2000. Official Methods of Analysis. 17th ed. AOAC International, Arlington, VA.

Balthazar, C.F., Silva, H.L.A., Celeguini, R.M.S., Santos, R., Pastore, G.M., Junior, C.C.A., Freitas, M.Q., Nogueira, L.C., Silva, M.C., Cruz, A.G. (2015). Effect of galactooligosaccharide addition on the physical, optical, and sensory acceptance of vanilla ice cream. J Dairy Sci, 98, 4266-4272.

Bolliger, S., Wildmoser, H., Goff, H.D., Tharp, B.W. (2000). Relationships between ice cream mix viscosity and ice crystal growth in ice cream Int Dairy J, 10, 791-797.

Çelik, H. (2004). Karadeniz için yeni bir meyve türü likapa (yaban mersini) (in Turkish). Ekoloji Magazin 1, 50-53.

Connor, A.M., Luby, J.J., Hancock, J.F., Berkheimer, S., Hanson, E.J. (2002). Changes in fruit antioxidant activity among blueberry cultivars during cold-temperature storage. J Agric Food Chem, 50, 893-898.

de Souza, V.R., Pereira, P.A.P., da Silva, T.L.T., de Oliveira Lima, L.C., Pio, R., Queiroz F. (2014). Determination of the bioactive compounds, 
antioxidant activity and chemical composition of Brazilian blackberry, red raspberry, strawberry, blueberry and sweet cherry fruits. Food Chem, 156, 362-368.

Diplock, A.T., Aggett, P.J., Ashwell, M., Bornet, F., Fern, E.B., Roberfroid, M.B. (1999). Scientific concepts of functional foods in Europe: Consensus document. Br J Nutr, 81, 1-27.

El-Nagar, G., Clowes, G., Tudorik, C.M., Kuri, V., Brennan, C.S. (2002). Rheological quality and stability of yog-ice cream with added inulin. Int $J$ Dairy Technol 55, 89-93.

Erkaya, T., Dağdemir, E., Şengül, M. (2012). Influence of Cape gooseberry (Physalis peruviana L.) addition on the chemical and sensory characteristics and mineral concentrations of ice cream. Food Res Int, 45,331-335.

Erlund, I., Koli, R., Alfthan, G., Marniemi, J., Puukka, P., Mustonen, P., Jula, A. (2008). Favorable effects of berry consumption on platelet function, blood pressure, and HDL cholesterol. Am J Clin Nutr, 87(2), 323-331.

Feinendegen, L.E., Kasperek, K. (1980). Medical aspects of trace element research. Trace Elem Anal Chem Med Biol, 45, 1-17.

Gidley, M.J. (2004). Naturally functional foodschallenges and opportunities. Asia Pac J Clin Nutr, 13, $31 \mathrm{p}$.

Gorski, D. (1997). American market trends. W. Buchheim (Ed.), Session V: Market trends in ice cream. Proceedings of the international symposium, International Dairy Federation, Athens, Greece, 145-151 pp.

Güler, Z. (2007). Levels of 24 mineral elements in local goat milk, strained yoghurt and salted yoghurt (tuzlu yoğurt). Small Rumin Res, 71,130137.

Gümüş, C., Ölmez, Z., Ölmez, G., Kalender, Ç. (2009). Artvin'de yaban mersini (Vaccinium sp., Likapa) yetiştiriciliği eğitimi konulu $\mathrm{AB}$ projesinin tanıtımı ve projenin yürütülmesinde karşılaşılan güçlükler ve sorunlar (in Turkish). II. Ormancilikta Sosyo-Ekonomik Sorunlar Kongresi, 19-21 Şubat, Isparta, 81-88.
Guven, M., Karaca, O.B. (2002). The effects of varying sugar content and fruit concentration on the physical properties of vanilla and fruit icecream-type frozen yogurts. Int J Dairy Technol, 55, 27-31.

Heinonen, I.M., Meyer, A.S., Frankel, E.N. (1998). Antioxidant activity of berry phenolics on human low-density lipoprotein and liposome oxidation. J Agric Food Chem, 46, 4107-4112.

Hwang, J.Y., Shyu, Y.S., Hsu, C.K. (2009). Grape wine lees improves the rheological and adds antioxidant properties to ice cream. LWT - Food Sci Technol, 42,312-318.

Jimenez-Florez, R., Klipfel, N.J. and Tobias, J. (1993). Ice cream and frozen desserts. In Dairy Science and Technology Handbook, Product Manufacturing (Y.H. Hui, ed.) pp. 57-159, VCH Publishers, New York, NY.

Kavaz Yuksel, A. (2015). The effects of blackthorn (Prunus spinosa L.) addition on certain quality characteristics of ice cream. J Food Qual, 38(6), 413-421.

Kong, J.M., Chia, L.S., Goh, N.K., Chia, T.F., Brouillard, R. (2003).Analysis and biological activities of anthocyanins. Phytochemistry, 64, 923933.

Konić-Ristić, A., Šavikin, K., Zdunić, G., Janković, T., Juranic, Z., Menković, N., Stanković, I. (2011). Biological activity and chemical composition of different berry juices. Food Chem, 125 (4), 1412-1417.

McDowell LR. 2003. Minerals in Animal and Human Nutrition, Elsevier Science B.V. Amsterdam, Netherland, 644 p.

Muse, M.R., Hartel, R.W. (2004). Ice cream structural elements that affect melting rate and hardness. J Dairy Sci, 87, 1-10.

Nair, A.R., Elks, C.M., Vila, J., Del Piero, F., Paulsen, D.B., Francis, J. (2014). A blueberryenriched diet improves renal function and reduces oxidative stress in metabolic syndrome animals: potential mechanism of TLR4-MAPK signaling pathway. PLoS One, 9 (11), e111976. 
Özer, B., Robinson, R.K., Grandison, A.S., Bell, A.E. (1997). Comparison of Techniques for Measuring the Rheological Properties of Labneh (Concentrated Yoghurt). Int J Dairy Technol, 50, 129-133.

Öztürk, H. İ., Demirci, T., \& Akın, N. (2017). Production of functional probiotic ice creams with white and dark blue fruits of Myrtus communis: The comparison of the prebiotic potentials on Lactobacillus casei 431 and functional characteristics. LWT. Food Sci Technol, 90, 339-345.

Pior, R.L., Cao, G., Martin, A., Sofic, E., McEwen, J., O’Brien, C., Lischner, N., Ehlenfeldt, M., Kalt, W., Krewer, G., Mainland, C.M. (1998). Antioxidant capacity as influenced by total phenolic and anthocyanin content, maturity, and variety of Vaccinium species. J Agric Food Chem, 46, 2686-2693.

Primetta, A.K., Jaakola, L., Ayaz, F.A., Inceer, H., Riihinen, K.R. (2013). Anthocyanin fingerprinting for authenticity studies of bilberry (Vaccinium myrtillus L.). Food Control, 30, 662-667.

Roland, A.M., Phillips, L.G., Boor, K.J. (1999). Effects of fat content on the sensory properties, melting, color, and hardness of ice cream. J Dairy Sci, 82, 32-38.

Saral, Ö., Ölmez, Z., Şahin, H. (2014). Comparison of antioxidant properties of wild blueberries (Vacinium arctostaphylos L. and Vaccinium myrtillus L.) with cultivated blueberry varieties (Vaccinium corymbosum L.) in Artvin region of Turkey. Turk Tarim Grda Bilim Teknol Derg, 3(1), 40-44.
Sellappan, S., Akoh, C.C., Krewer, G. (2002). Phenolic compounds and antioxidant capacity of Georgia-grown blueberries and blackberries. J Agric Food Chem, 50(8): 2432-2438.

Sofjan, R., Hartel, R.W. (2004). Effects of overrun on structural and physical characteristics of icecream. Int Dairy J, 14, 255-262.

Subash, S., Essa, M.M., Al-Adawi, S., Memon, M.A., Manivasagam, T., Akbar, M. (2014). Neuroprotective effects of berry fruits on neurodegenerative diseases. Neural Regen Res, 9(16), 1557.

Sweeney, M.I., Kalt, W., MacKinnon, S.L., Ashby, J., Gottschall-Pass, K.T. (2002). Feeding rats diets enriched in lowbush blueberries for six weeks decreases ischemia-induced brain damage. Nutr Neurosci, 5(6), 427-431.

Szefer, P., Nriagu, J.O. (2007). Mineral Components in Foods. CRC Press, New York, NY. Van Kleef, E., Van Trijp, H.C., Luning, P., Jongen, W.M. (2002). Consumer-oriented functional food development: how well do functional disciplines reflect the 'voice of the consumer'?. Trends Food Sci Technol, 13(3), 93-101.

Şimşek, A., Sarı, F., Artık, N. (2004). Selenyumun insan beslenmesi ve sağlı̆̆1 açısından önemi. Anadolu Unvv J Sci Technol, 5 (2), 245-251.

Yüksel, A.K., Yüksel, M., Şat, İ.G. (2017). Determination of certain physicochemical characteristics and sensory properties of green tea powder (matcha) added ice creams and detection of their organic acid and mineral contents. GIDA/ J Food, 42 (2): 116-126. 